\title{
EFFECT OF CHOPPING STEP AND DRYING TECHNIQUE ON THE QUALITY OF ALKALI TREATED COTTONII (ATC)
}

\author{
Pengaruh Tahap Pencacahan dan Teknik Pengeringan \\ terhadap Mutu Alkali Treated Cottonii (ATC)
}

\author{
Singgih Wibowo ${ }^{1)^{*}}$, Muhamad Darmawan ${ }^{1)}$, Arif Rahman Hakim¹), Seruni Marsella ${ }^{2)}$ \\ ${ }^{1)}$ Research and Development Center for Marine and Fisheries Product Processing and Biotechnology \\ ${ }^{2}$ Swiss German University, Serpong, Tangerang \\ *Corresponding author: paksingh@yahoo.com. KS. Tubun Petamburan VI, Jakarta Pusat 10260
}

\begin{abstract}
A research related to the production of alkali treated cottonii (ATC) had been carried out in order to study the effect of chopping step and drying techniques on the quality of ATC produced. Four treatments were applied in the experiment, namely was copping before sun drying (treatment A); chopping after sun drying (B); chopping before mechanical drying (C); and chopping after mechanical drying (D). The quality parameters of ATC measured were gel strength, moisture content, viscosity, yield, and whiteness. The results showed that the quality of ATC was significantly affected by chopping step and drying technique, especially in ATC gel strength, viscosity and yield. However, the effect of chopping step and drying technique was insignificant to ATC moisture content and whiteness. Chopping seaweed before drying resulted in higher gel strength of the ATC but lower in yield, while chopping after drying tended to result in lower gel strength but higher viscosity and yield.
\end{abstract}

Keywords: drying technique, alkali treated cottonii (ATC), chopping step, quality

\begin{abstract}
ABSTRAK
Penelitian yang berkaitan dengan produksi alkali treated cottonii (ATC) telah dilakukan untuk mempelajari pengaruh tahapan pencacahan rumput laut dan cara pengeringan terhadap mutu ATC yang dihasilkan. Empat perlakuan digunakan di dalam penelitian ini, yaitu pencacahan sebelum pengeringan dengan penjemuran (perlakuan $A$ ); pencacahan setelah pengeringan dengan penjemuran (B); pencacahan sebelum pengeringan dengan pengering mekanis (C); dan pencacahan setelah pengeringan dengan pengering mekanis (D). Parameter mutu yang diamati adalah kekuatan gel, kadar air, viskositas, rendemen, dan derajat keputihan ATC yang dihasilkan. Hasil analisis menunjukkan bahwa mutu ATC dipengaruhi oleh tahapan pencacahan dan cara pengeringan, terutama terhadap kekuatan gel, viskositas, dan rendemen. Pencacahan rumput laut sebelum penjemuran menghasilkan ATC dengan kekuatan gel tinggi tetapi viskositas dan rendemen lebih rendah, sedangkan pencacahan setelah pengeringan menghasilkan kekuatan gel yang lebih rendah tetapi dengan viskositas dan rendemen yang tinggi.
\end{abstract}

Kata Kunci: teknik pengeringan, Alkali Treated Cottonii (ATC), tahap pencacahan, mutu

\section{INTRODUCTION}

Seaweed culture in Indonesia has been well grown rapidly in accordance with the increasing demand of seaweed from importing countries. Indonesia has targeted to produce 10 million tons of wet seaweed by 2015 (Antara, 2011) equal to approximately 1 million of dry seaweed. Eucheuma cottonii is one of seaweed species cultivated in Indonesia, especially in the eastern part. This type of seaweed is in high demand in the market. The demand for export for $E$. cottonii in
2002 was very high, reaching 559,888,073 kg which is usually used to produce carrageenan. Carrageenan is a natural linear polysaccharide extracted from red seaweeds (Gigartinales, Rhodophyta) and is extensively used as thickeners, gelling, texturizing, suspending or stabilising agents in various industrial applications ranging from food products to pharmaceutical products and even for chemical industries purposes (Piculell, 1995; Bixler, 1996).

In the food industry, carrageenans are widely utilized due to their excellent physical functional 
properties, such as thickening, gelling and stabilizing abilities, and have been used to improve the texture of cottage cheese, to control the viscosity and texture of puddings and dairy desserts, and as binders and stabilizers in the meat-processing industry for the manufacture of patties, sausages and low-fat hamburgers. The food industry accounts for $70-80 \%$ of the total world production, estimated at about 45,000 metric tonnes per year, of which about $45 \%$ goes to dairy products and $30 \%$ to meat and meat derivatives. The total market of carrageenans has been estimated as US $\$ 300$ million/year (McHugh, 2003).

Carrageenans are also used in various non-food products, such as pharmaceutical, cosmetics, printing and textile formulations (Imeson, 2000). Carrageenans stabilize toothpaste preparations, absorb body fluids when formulated in wound dressings and interact with human carotene to give soft skin and silky hair in hand lotions and shampoos, respectively. They have proved to be useful as tableting excipients due to the good compatibility, high robustness and persistent viscoelasticity of the tablet during compression. These interesting properties indicated that carrageenans are suitable excipients for sustained-release formulations (Bhardwaj et al., 2000).

E.cottonii can be preserved into alkaline treated cottonii (ATC), or processed into semi refined carrageenan (SRC) and refined carrageenan (RC) which are different quality in term of purity. The purer the quality of carrageenan the higher the market value will be. Marketing of $E$. cottonii in dried form will result in low revenue while processing it into a purer carrageenan such as $\mathrm{RC}$ will produce higher revenue with the consequences of requiring more complicated technology as well as higher cost of production.

Processing the seaweed into ATC, a chips of treated cottonii, will require simpler technology and cheaper in cost production compared to RC and is expected more suitable for Indonesia. The solution of potassium hydroxide $(\mathrm{KOH})$ at high temperature is employed to reduce the sulphate content in the seaweed. In such process, cation of $\mathrm{K}^{+}$dissociated from $\mathrm{KOH}$ will affect the gel strength of ATC which is usually used as an important quality parameter. Producing high quality of ATC will also influence by the drying process which is expected to produce 12$14 \%$ of moisture content. The chopping step, whether performed before or after drying, will probably affect the quality of ATC, especially the gel strength. The aim of this research is to study the effect of chopping step and drying techniques on the quality of ATC produced.

\section{MATERIALS AND METHODS}

\section{Seaweed Materials}

Seaweed used in this research was purchased from the collector located in Bulak Kapal, Tabanan, Bali in April 2011. The seaweed was sorted to remove filth or any non-algal materials such as rope, sand and other materials found in the seaweed. This process is also aim to remove other seaweed species than $E$. cottonii. The $E$. cottonii was then packed into plastic bag and transported to the Processing Laboratory of Research and Development Center for Marine and Fisheries Product Processing and Biotechnology in Jakarta.

\section{Processing of ATC}

To produce ATC, sorted E. cottonii was washed and then boiled in $\mathrm{KOH}$ solution. The alkali treated seaweed was then dried. Chopping seaweed could be performed before drying or after drying.

As much as $50 \mathrm{~kg}$ of dried seaweed was washed by using washing machine which was operated at 8 rpm for $20 \mathrm{~min}$. The clean seaweed was drained and boiled in the solution of $8 \% \mathrm{KOH}$ at $80^{\circ} \mathrm{C}$ for 2 hours. The treated seaweed was rinsed until the water $\mathrm{pH}$ was neutral or rinsed for at least 3 times and drained.

The batch of treated seaweed was then equally divided into 4 parts for the experiment. The experiment was designed to apply drying techniques (sun drying and mechanical drying) and chopping steps (chopping before drying and after drying). Based on the design, the treatments employed in this experiment were set as follow.
A: Chopping before sun drying
$B$ : Chopping after sun drying
C: Chopping before mechanical drying
D: Chopping after mechanical drying

In the treatment $A$, the drained alkali treated seaweed was chopped into wet chips which were then dried by using sun drying technique. In the treatment $B$, the drained alkali treated seaweed was dried by using sun drying and then chopped into chips. Treatment $C$ was the same as treatment $A$, but the chopped seaweed was dried by using mechanical drier. Treatment $D$ was the same as treatment $B$, but the drying technique used was mechanical drying.

\section{Parameter of analysis}

Several characteristics of raw materials, namely moisture content, acid insoluble ash content, clean anhydrous weight (CAW) and sand content (filth) were 
Table 1. Characteristics of seaweed as raw material

evaluated. The quality parameters of ATC evaluated were gel strength (Marine Colloids, 1978), moisture content AOAC, 1995), viscosity (Marine Colloids, 1977), yield (Marine Colloids, 1978), and whiteness (Saito, 2004). In this experiment, the sampling for analysis was taken randomly with 3 replications and the statistical analysis was performed by using SPSS 15.

\section{RESULTS AND DISCUSSION}

\section{Characteristic of Raw Material}

Results of the analysis on the characteristic of seaweed collected from Bali used as raw material in this experiment are shown in Table 1.

According to Table 1, moisture content of seaweed used for the experiment was $56.83 \%$. Considering that standard of moisture content issued by FAO for dried E. cottonii is less than $40 \%$ (Anon., 1978), moisture content of the seaweed from Bali was lower. As the lower the moisture content, the smaller the probability of seaweed to be deteriorated and fermented, it means that based on the moisture content, the raw material used in the experiment was good. Meanwhile, the ash content of the seaweed was $29.76 \%$. The ash content in seaweed is commonly originated from sodium salts derived from seawater. Hirao (1971) confirmed that ash content of seaweed is usually $15-40 \%$.

The acid insoluble ash of the seaweed, which was quantified as ash that insoluble in hydrochloric acid, was $0.25 \%$ that met with the FAO standard of less than 1\% (Anon., 1978). Another important parameter for dried seaweed is clean anhydrous weight (CAW) which shows the purity of the seaweed. The CAW of the sample was $36.97 \%$ which is higher than FAO standard of less than $30 \%$ (Anon., 1978). Meanwhile, the sand content of the seaweed was $1.09 \%$. This high CAW and sand content indicated that the seaweed used in this experiment was dried improperly. Proper drying of seaweed by using a para-para or on the covered ground (Aji et al., 2003) is required to produce a good quality of dried seaweed.

\section{Gel strength}

The gel strength of ATC in this experiment is presented in Figure 1. Gel strength is one of the very important parameter for ATC which is commonly used as main requisite by ATC industries.

The gel strength of ATC resulted from all treatments ranged from $430.58 \mathrm{~g} / \mathrm{cm}^{2}$ to $1,136.83 \mathrm{~g} / \mathrm{cm}^{2}$. Figure 1 shows that all gel strength results were within the standard of $F A O$ which is required to be larger than $400 \mathrm{~g} / \mathrm{cm}^{2}$ (Anon., 1978). Statistically, gel strength of ATC resulted from both drying techniques was significantly different $(p<0.05)$. The highest value was obtained by treatment $A$ (chopping before sun-drying) and the lowest was obtained by treatment $D$ (chopping after mechanical drying). As shown in Figure 1, it seems that gel strength of ATC resulted from all treatments was very much affected by the chopping step. Chopping the seaweed before sun-drying (treatment $A$ ) resulted in higher gel strength of ATC compared to chopping after sun-drying (treatment $B$ ). Similarly, chopping before mechanical drying (treatment C) resulted in higher gel strength of ATC compared to chopping after mechanical drying (treatment D).

These findings indicate that chopping before drying will be able to result in higher gel strength of ATC. In other word, it can be said that chopping should be performed before drying in order to produce ATC with high gel strength. The gel strength is basically affected by temperature of processing. Meanwhile, chopping could increase the temperature of seaweed, particularly when the seaweed is dry. Chopping the seaweed before drying when the seaweed still is wet might be effective on eliminating the increasing temperature during the chopping. The presence of moisture in the wet seaweed when was chopped might played an important role in compensating the increasing temperature. Consequently, it will produce high gel strength of ATC.

Several factors may affect the gel strength value. Gel strength of ATC increases proportionally to the 36 -anhydrogalactose content but decreases 


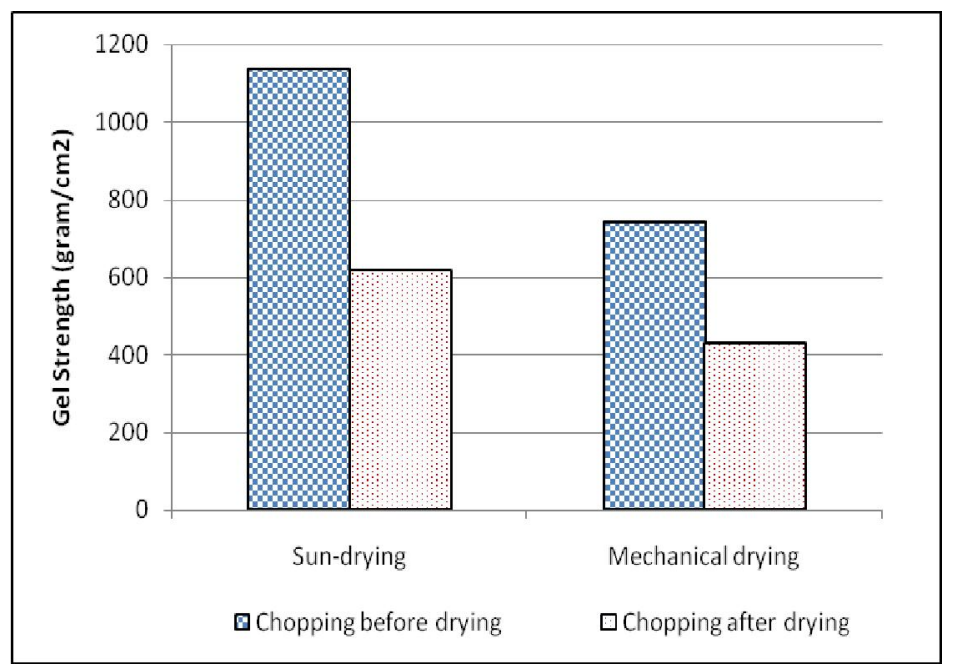

Figure 1. Effect of chopping step and drying technique on the gel strength of ATC.

proportionally to the sulphate content (Suryaningrum, 1988). The conversion of C-6 sulphate to 3-6anhydrogalactose is clearly creating new strong component. The 3-6-anhydrogalactose causes the anhydrophilic behavior and increases the formation of double helix which is in turn will yield in high gel strength. Other factors that influence the high gel strength of ATC are raw material condition, age of cultivation, method of extraction and type of chemical used for extraction (Samsuari, 2006).

\section{Moisture content}

The moisture content of ATC resulted in this experiment as presented in Figure 2 was ranged from $11.54 \%$ to $15.06 \%$. Figure 2 showed that highest moisture content of ATC was obtained by treatment B (chopping after sun-drying), while lowest moisture content of ATC was by treatment A (chopping before sun-drying). Statistically, moisture contents of all treatments were significantly different $(p<0.05)$. However, the moisture content was not significantly affected by chopping step or drying technique. There was no certain pattern that can be drawn from this result. Amongst the results, chopping before sundrying (treatment $A$ ) resulted in ATC with moisture content less than the FAO standard of $12 \%$ (Anon., 1978). Nonetheless, drying time could be arranged to meet FAO standard for moisture content.

\section{Viscosity}

Other quality parameter of ATC observed in this experiment was viscosity and the result is presented in Figure 3 . The viscosity of ATC resulted from the experiment were between 292.50 cPs and 625.50 cPs.

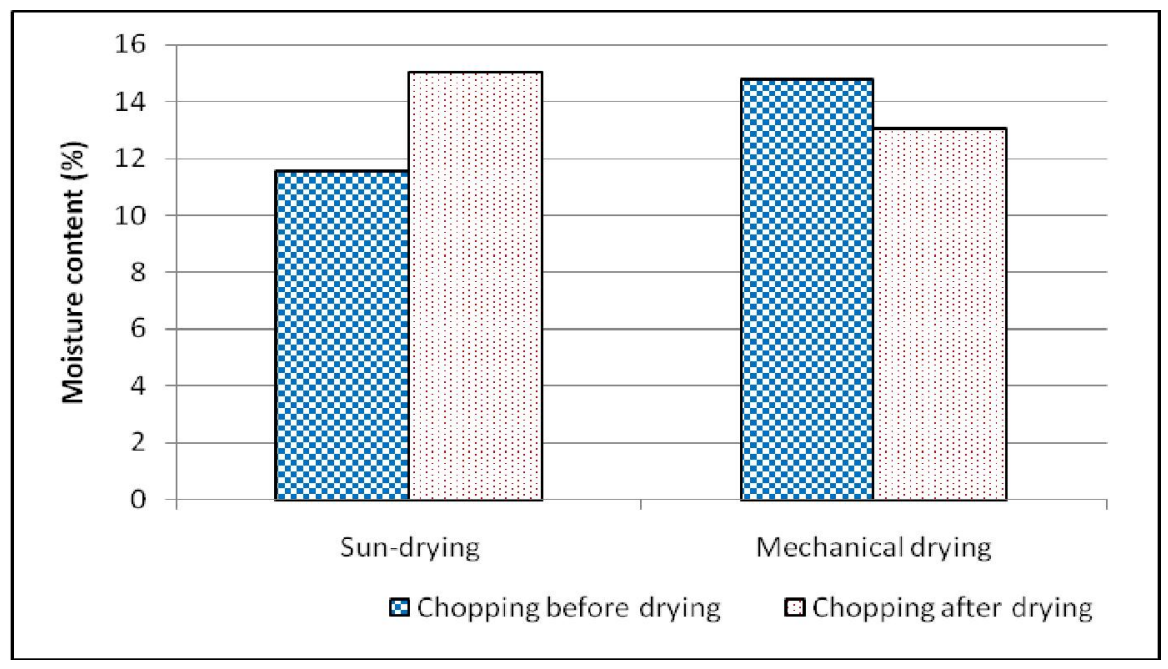

Figure 2. Effect of chopping step and drying technique on moisture content of ATC. 


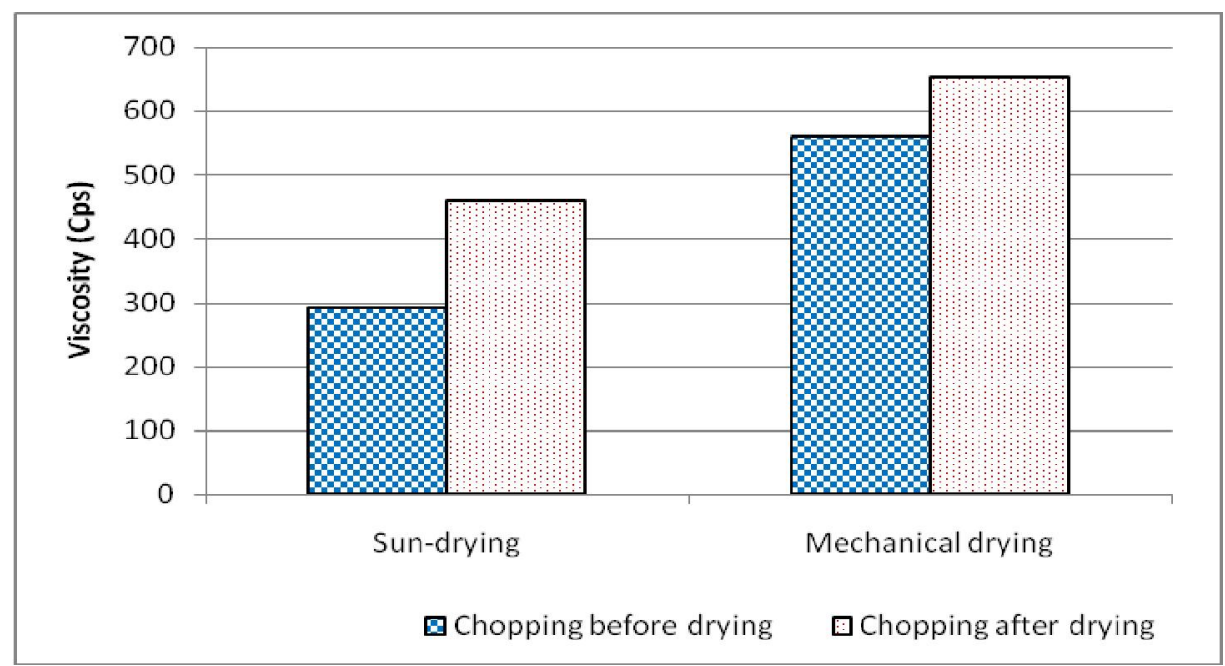

Figure 3. Effect of chopping step and drying technique on the viscosity of ATC

The statistical analysis result showed that there was significant different on viscosity amongst the treatments $(p<0.05)$. As shown in Figure 3, chopping after mechanical drying (treatment D) resulted in ATC with highest viscosity while the lowest viscosity was resulted from chopping before sun-drying (treatment A). Compared to the FAO standard on viscosity requiring viscosity greater than $5 \mathrm{cPs}$, all ATCs produced were within the standard (Anon., 1978).

These viscosities were inversely related to gel strength results (Moirano, 1997) as previously discussed. ATC resulted from treatment A (chopping before sun-drying) showed lowest viscosity (Figure 3 ) which inversely showed highest gel strength (Figure 1). There are several factors affect the viscosity of hydrocolloids such as ATC. They were the concentration of alkali, extraction temperature, degree of dispersion, sulphate content, treatment given to the seaweed, and the presence of electrolyte and nonelectrolyte in the system (Saleh et al., 1994). The sulphate groups in the polymers chain have negative charges causing the repulsion along polymer chain and rigidness of polymer chain (Guiseley et al., 1980). The viscosity will affect the gelling point and melting point of the hydrocolloids. High viscosity of carragenan solution, for example, produces rapid melting point in contrast to low viscosity that causes gel formation.

\section{Yield}

Other important parameter of ATC quality observed was the yield as presented in Figure 4. As in Figure 4 , the yield of ATC resulted from the treatment were between $31 \%$ and $36.10 \%$. Statistically, the result showed that yield of ATC was significantly affected by both chopping steps and drying technique $(p<0,05)$. The Figure shows a tendency that chopping step

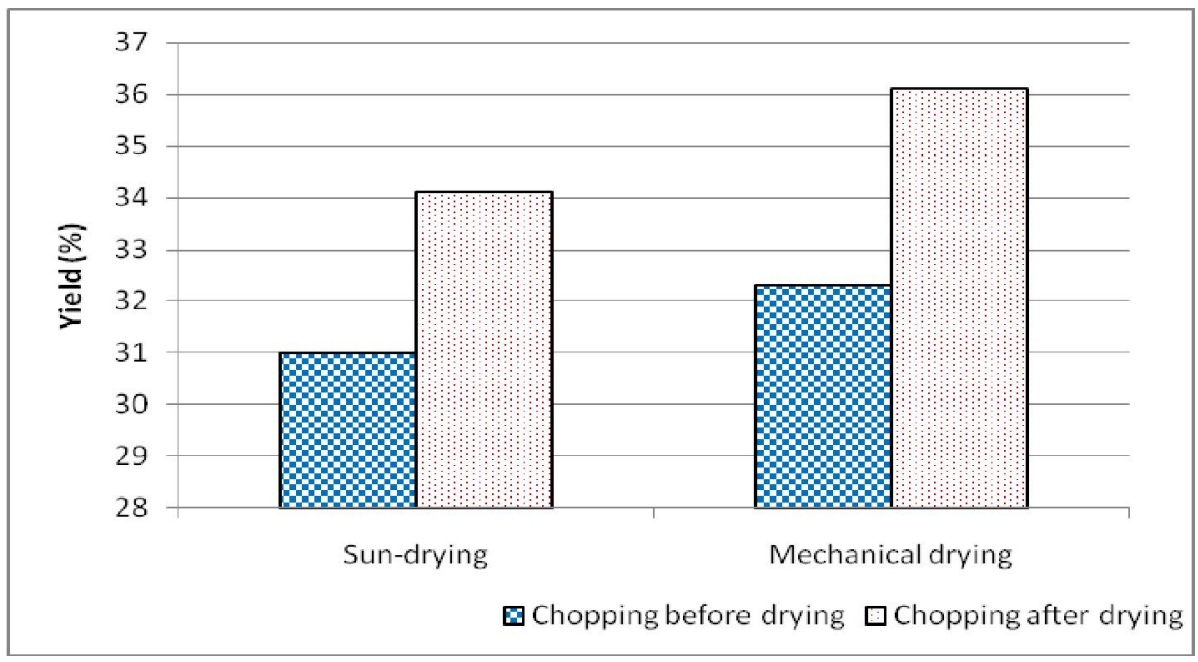

Figure 4. Effect of chopping step and drying technique on the yield of ATC. 
affected more to the yield of ATC compare to drying technique. The yield of ATC resulted from sun drying was lower than mechanical drying for both chopping before and after drying. Meanwhile, chopping before drying resulted in lower yield compared to chopping after drying. In the contrary, as shown in Figure1, the gel strength of ATC was higher when the seaweed was chopped before drying. These mean that chopping before drying will result in high gel strength but low in yield. In the contrary, the gel strength of ATC will be lower when seaweed was chopped after drying but the yield was higher. Based on these findings, it can be said that when high gel strength of ATC is an important parameter to be achieved, therefore chopping before drying will be favorable for ATC processing with the consequences of producing low yield of ATC. However, when the gel strength is not the critical requirement for ATC, then, chopping after drying will be more advantageous for ATC processing. Chopping after drying in the ATC processing produces higher yield and consequently will economically be more profitable.

Chopping before drying will produce more surface area on the seaweed so then the seaweed has more opportunity to have contact with the alkali in the extraction process. This condition will then increase the melting point of carrageenan allowing it to be extracted out of the cells easily (Widiastuti, 1990). The free carrageenan will then interacted with the sulphate group easily. As a result, a great numbers of 3,6-anhydrogalactose release from the sulphate groups resulting in lower gel strength (Suryaningrum, 1988) and higher yield. However, since yield is also depending on the climate, method of extraction, age or harvesting time and location of cultivation (Chapman \& Chapman, 1980), therefore, it is interesting to find out whether the result will be the same for different seaweed collected from different harvesting time (age) and location of cultivation.

\section{Whiteness}

Other important parameter for ATC quality is degree of whiteness. Figure 6 . bellow shows the whiteness result from all treatments. As shown in Figure 6, the highest whiteness of ATC was obtained from chopping before sun drying $(58,88 \%)$ and the lowest one was from chopping after mechanical drying $(50,55 \%)$. The result indicated that whiteness of ATC was not significantly affected by the chopping step. The whiteness of ATC was not depending on whether the seaweed chopped before or after drying. Figure 5 showed an indication that the whiteness of the ATC was depending on drying technique used. Sun drying tended to produce whiter ATC compare to mechanical drying did. This finding might related to the role of UV light transmitted by the sun. However, statistically, the different was not significant $(p<0,5)$. The whiteness of ATC is expected high near to $100 \%$ in order to provide more chance to ATC for wider application (Agustine, 2011; Samsuari, 2006). A turbid, vague, blurred or unclear color of ATC will give unattractive color to products.

The whiteness of ATC is affected by the raw material, the drying method applied (Agustine, 2011), also heat and concentration of alkali solution used in the process (Saleh, 1994; Antelo et al., 2008). The alkali solution will oxidize the pigment and brighten the seaweed. Chemically, colorant molecules contain double bonds and the process of whitening is an oxidation or reduction process occurred in the double bond (Saleh, 1994). Alteration of this double bond creates a new molecule which does not responsible to color. Moreover, heat treatment as applied in the alkali treatment and drying in the ATC production is

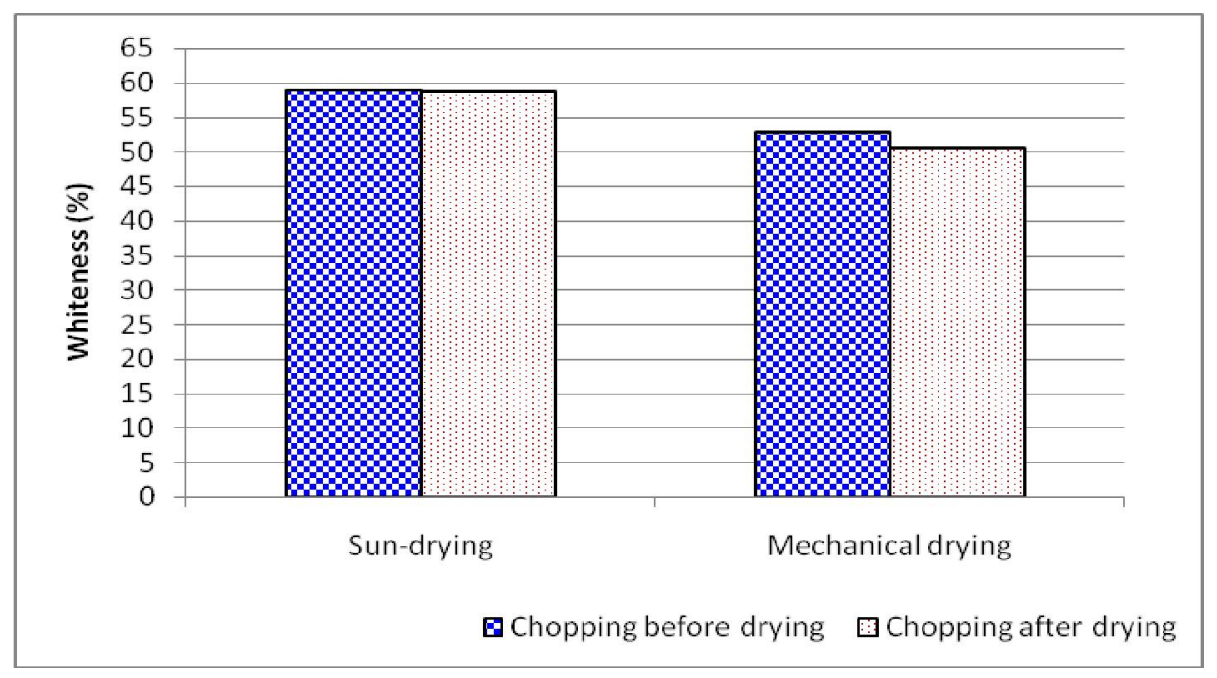

Figure 5. Effect of chopping step and drying technique on the whiteness of ATC. 
able to degrade the pigments in seaweed. Heat which degrades protein chain in the pigment will yield decolorization in seaweed (Antelo et al., 2008).

\section{CONCLUSION}

The quality of ATC was significantly affected by chopping step and drying technique, especially in ATC gel strength, viscosity and yield. The effect of chopping step and drying technique was insignificant to ATC moisture content and whiteness. Chopping before drying (sun or mechanical drying) was favorable for ATC processing producing high gel strength of ATC with the consequences of producing lower yield of ATC. When gel strength of ATC is not the critical requirement for ATC, chopping after drying will economically be more profitable for ATC processing resulting in ATC with higher yield but lower gel strength.

\section{REFERENCES}

BSN. 2006. Cara Pengujian Bakteri TPC. SNI 01-2332.32006. Badan Standardisasi Nasional. Jakarta.

Agustine, P. 2011. "Pengaruh Waktu Pemanasan dan Konsentrasi Bahan Pemucat (kaporit) Terhadap Mutu Alkali Treated Cottonii (ATC) dari Rumput Laut." [thesis]. Faculty of Science and Technology. University of Al Azhar Indonesia, Jakarta. P. 48.

Aji, N., Ariyani, F., dan Suryaningrum, T. Pengeringan dan Sortasi. 2003. Teknologi Pemanfaatan Rumput Laut, Pusat Riset Pengolahan Produk dan Sosial Ekonomi Kelautan dan Perikanan. Jakarta. p. 13.

Anonymous. 1978. Raw Material Test Laboratory Standard Practice. Marine Colloids Div. Corps. Springfield. USA. pp. 79-92.

Antara. 2011. Indonesia produces 10 million tons of seaweed. http://bali.antaranews.com/berita/9613/ indonesia-produksi-rumput-laut-10-juta-ton. accessed june 12 .

Antelo, F.S., Costa, J.A.V., and Kalil, S.J. 2008. Thermal Degradation Kinetics of the Phycocyanin from Spirulina Plantensis. Biochemistry journal.

AOAC. 1995. Official Methods of Analysis of the Association of Official Analitycal Chemist. Inc. Washington DC. pp.185-189.

Bhardwaj, T.R., Kanwar, M., Lal, R., and Gupta, A. 2000. Natural gums and modified natural gums as sustained-release carriers. Drug Development and Industrial Pharmacy, 26: pp. 1025-1038.

Bixler, H.J. 1996. Recent developments in manufacturing and marketing carrageenan. Hydrobiologia. 326/327: 35-57.

Chapman, V.J. and Chapman, D.J. 1980. Seaweeds and Their Uses. Third Edition. Chapman and Hall. London, New York. p. 333.
Guiseley, K.B., Stanley, N.F., and Whitehouse, P.A. 1980. Carrageenan. In: Davids RL (editor). Hand Book of Water Soluble Gums and Resins. Mc Graw Hill Book Company. New York, Toronto, London. pp. 125-142.

Hirao, S. 1971. Seaweed in Utilization of Marine Products. In: Osaka, M.; Hirao, S.; Noguchi, E.; Suzuki, T.; and Yokoseki, M. (吕itors). Overseas Technical Cooperation Agency Goverment of Japan. p. 148.

Imeson, A. 2000. Carrageenan. Woodhead Publishing Limited and CRC Press LLC.

Marine Colloids. 1977. Carrageenan. Marine Colloid Monograph Number One. Marine Colloids FMC Corp. Springfield, New Jersey. USA.

Marine Colloids. 1978. Marine Colloids FMC Corp. "Raw Material Test Laboratory Standart Practise". Springfield, New Jesey. USA.

McHugh, D.J. 2003. A guide to the seaweed industry: FAO fisheries technical paper No. 441 FAO. Rome. pp. 61-72.

Moirano AL. 1977. Sulphated Seaweed Polysaccarides. In: Graham HD (editor). Food Colloids the AVI Publishing. Westport. Conn. pp. 347-381.

Piculell, L. 1995. Gelling carrageenans. In: A. M. Stephen (editor), Food polysaccharides and their applications. Marcel Dekker. New York. pp. 205-244.

Saito, M., Kudo, H., Mandarin, J.M.G., and Benassi, V.T. 2004. Effects of Variety and Cultivating Region on the Color of Soymilk and Other Soybean Processing Foods in Brazil. Japan International Research Center For Agricultural Sciences (JIRCAS)

Saleh. M., Herdian, P.D., Suptijah, J., Santoso, dan Indriati, N. 1994. Pengaruh perendaman dalam bahan pemucat terhadap mutu dan rendemen Karaginan dari rumput laut. Jurnal Penelitian Pasca Panen Perikanan. 82: 1-15

Samsuari. 2006. Penelitian Pembuatan Karaginan dari Rumput Laut Eucheuma cottonii di Wilayah Perairan Kabupaten Jeneponto propinsi Sulawesi Selatan. Institut Pertanian Bogor.

Sen, O.P. 2005. Total Plate Count. Advances in Fish Processing Technology. ALLIED Publisher. New Delhi. p. 690.

Soegiarto, A. and Sulustijo. 1990. Utilization and farming of seaweeds in Indonesia. In: Dogma Jr.I.J.; Trono Jr.G.C.; and Tabbada, R.A. (editors). Culture and use of algae in Southeast Asia: Proceedings of the Symposium on Culture and Utilization of Algae in Southeast Asia, 8-11 December 1981, Tigbauan, Iloilo, Philippines. pp. 9-19.

Suryaningrum, T.D. 1988. Kajian sifat-sifat mutu komoditas rumput laut budidaya jenis Eucheuma cottonii dan Eucheuma spinosum. [tesis]. Bogor: Program Pasca Sarjana Institut Pertanian Bogor. p. 181.

Widiastuti, H.N. 1990. Pengaruh Konsentrasi $\mathrm{NaOH}$ Terhadap Sifat-sifat Karaginan Eucheuma cottonii dari Karimun Jawa dan Madura. Universitas Diponegoro. 